Article

\title{
The PROMETHEE Framework for Comparing the Sustainability of Agricultural Systems
}

\author{
Byomkesh Talukder 1,*(1) and Keith W. Hipel 2,3 \\ 1 Dahdaleh Institute for Global Health Research, York University, Suite 2150, 88 The Pond Road, Toronto, \\ ON M3J 2S5, Canada \\ 2 Conflict Analysis Group, Department of Systems Design Engineering, University of Waterloo, Waterloo, \\ ON N2L 3G1, Canada; kwhipel@uwaterloo.ca \\ 3 Centre for International Governance Innovation and Balsillie School of International Affairs, Waterloo, \\ ON N2L 6C2, Canada \\ * Correspondence: byomkesh.talukder@gmail.com; Tel.: +1-226-600-0730
}

Received: 24 August 2018; Accepted: 9 November 2018; Published: 13 November 2018

check for updates

\begin{abstract}
The PROMETHEE (Preference Ranking Organization Method for Enrichment Evaluation) method is applied to five different types of agricultural systems in coastal Bangladesh in order to rank the alternatives from most to least suitable according to a range of sustainability indicators. More specifically, composite indicators from six sustainability categories-productivity, stability, efficiency, durability, compatibility, and equity-are used for this assessment. The case study demonstrates that PROMETHEE constitutes a flexible MCDA (Multi-Criteria Decision Analysis) tool to investigate the sustainability of agricultural systems, rank the different alternative systems, and provide valuable insights.
\end{abstract}

Keywords: agricultural sustainability assessment; MCDA; PROMETHEE; composite indicators

\section{Introduction}

In the present world context, given the potential for agricultural systems to eradicate poverty and ensure sustainable development in the coming decades [1], understanding the extent of sustainability for agricultural systems is essential. Accordingly, there is a growing desire among researchers and policymakers for a systematic method to conduct situational analyses, frame issues, assess risks/vulnerability to food security and integrate efforts towards sustainability using evidence-based policy recommendations [2-5]. "Assessments today need to help reverse trends towards deeper un-sustainability and address the unavoidable interconnections, feedbacks, and uncertainties that typify complex socio-ecological systems at all scales" ([6] p. 233).

The importance of agricultural sustainability assessments has given rise to the key question of what frameworks are appropriate and acceptable in different socio-ecological contexts [7]. As many as 120 approaches have been developed to assess the sustainability of agricultural systems [8,9]. Among these, Response-Inducing Sustainability Evaluation (RISE) [10], Sustainability Assessment of Farming and the Environment (SAFE) [11], Indicateurs de Durabilité des Exploitations Agricoles or Farm Sustainability Indicators (IDEA) [12], Monitoring Tool for Integrated Farm Sustainability (MOTIFS) [13], Integrated assessment of agricultural systems-A component-based framework for the European Union (SEAMLESS) [14], Multi-Criteria Decision Analysis (MCDA) [15], MESMIS Program (acronym for Indicator-based Sustainability Assessment Framework) [4], and Sustainability Assessment of Food and Agriculture Systems (SAFA) [8] are holistic frameworks that consider social, economic, and environmental aspects to assess sustainability. 
RISE, IDEA, SAFE, MCDA, and SAFA measure social, economic, and environmental indicators separately rather than as aggregate indicators in a single index. Decision makers often do not have enough time to understand all the procedures of agricultural sustainability assessment, in which case viewing the final results is very important. This requires a methodology that generates a final score for assessment. In particular, MCDA-based agricultural sustainability assessment, specifically Multi-Attribute Utility Theory (MAUT), has recently been applied in agricultural sustainability assessment by Dantsis et al. [15] and Talukder et al. [16]. In both papers, MCDA combines and aggregates economic, environmental, and social indicators in order to quantify sustainability in a holistic manner and prioritize the sustainability performance of agricultural systems through incorporating stakeholder inputs in the form of weighting. This allows for the integrated assessment as it handles data from the three pillars of sustainability. MAUT-based methods combine and aggregate sustainability indicators in order to quantify the objectives in a holistic manner. They are able to consider the economic, environmental, and social issues; evaluate the performance of agricultural systems based on selected criteria or indicators and prioritize the performance of the systems; incorporate the input of stakeholders in the form of weighting; handle both qualitative and quantitative indicators; and calculate the degree of sustainability at the farm level [15].

However, MAUT does not allow for the one-on-one comparison of the indicators of agricultural sustainability assessment. Therefore, while the MAUT-based MCDA approach is a good sustainability assessment tool, there is still room to investigate the applicability of other MCDA techniques like PROMETHEE in order to identify the ones that are most appropriate to assess agricultural sustainability. With this background, the main objective of this paper is to investigate the applicability of PROMETHEE-GAIA (Geometrical Analysis for Interactive Assistance), an MCDA technique, to assess agricultural sustainability. A secondary objective is to identify both the benefits and obstacles of using PROMETHEE as a tool for agricultural sustainability assessment.

\section{MCDA and Sustainability Assessment}

MCDA is a well-known branch of Decision Theory [17] that consists of a group of approaches which account explicitly for multiple indicators in order to support individuals or groups to rank, select and/or compare different alternatives $[18,19]$. "Decision theory provides a rational framework for choosing between alternative courses of action when the consequences resulting from this choice are imperfectly known. Two streams of thought serve as the foundations: utility theory and the inductive use of probability theory" ([20] p. 200). MCDA facilitates decision making (such as evaluation, prioritization, and selection) in the presence of many conflicting choices and criteria or indicators [21-23]. It can rank decisions, distinguish satisfactory decision options from unacceptable possibilities, and identify the single most preferred decision [24]. Importantly, MCDA techniques take into account a wide range of dissimilar but relevant criteria [18,25].

MCDA may be carried out using various methods, including the application of computer software. Generally, MCDA follows four phases [26,27]. It starts by defining objectives, after which the criteria are chosen to measure the objectives and then alternatives are then specified. Once the criteria and alternatives are established, the criteria of different scales are transformed into commensurable units and weights are assigned subsequently to reflect the relative importance of the criteria. In the last phase, mathematical algorithms are selected and applied for ranking or choosing alternatives [28]. The literature highlights a number of strengths and weaknesses of MCDA. The comparative strengths and weaknesses of different MCDA methods are presented in Belton and Stewart [18], who find that MCDA offers a process that leads to rational, transparent, justifiable and explainable decisions that can serve as a focus for discussion, whereas the weakness of MCDA lies mostly in the subjectivity of the weighting process [29]. The techniques of MCDA belong to different "axiomatic groups" or "schools of thought" ([28] p. 5). Psomas et al. ([30] p. 3) categorized MCDA approaches into four groups: (a) the Value System techniques such as the Analytic Hierarchy Processes(AHP)/Analytic Network Processes (ANP) [31,32] and the Multi-Attribute Value Theory(MAVT)/Multi-Attribute 
Utility Theory (MAUT) [33,34]; (b) the Outranking Relations procedures like ELECTRE [35], PROMETHEE [36], plus other Outranking approaches including TOPSIS [37,38] and VIKOR [38]; (c) the Disaggregation-Aggregation Approach [34]; and (d) the Multi-Objective Optimization [34] procedure. MCDA has been used extensively to evaluate sustainability in many different sectors for which a good overview is provided by Cinelli et al. [39]. Sustainability assessment is essentially a multi-criteria issue expressed using indicators as it must consider and integrate indicators reflecting economic, social and environmental dimensions [40,41]. MCDA has the capacity for the integrated sustainability assessment because it can consider multiple criteria [39], and many of its techniques have been successfully applied to a range of sustainability challenges. In particular, PROMETHEE is being used in the areas of environmental management, hydrology and water management, agriculture, education, and government, among other domains [42].

\section{MCDA in Agricultural Sustainability Assessment}

Agricultural sustainability assessment is a key step in the implementation of sustainable agricultural systems since an assessment will identify the status of the sustainability issues of the agricultural systems and forms the basis upon which meaningful actions and policies can be implemented to make agriculture sustainable. A realistic assessment of sustainability requires (1) the integration of diverse information concerning sustainability objectives and (2) the handling of conflicting aspects of these objectives as a function of the views and opinions of the individuals involved in the assessment process. The assessment of agricultural sustainability is therefore increasingly regarded as an issue of multi-criteria decision analysis [43].

Like other types of sustainability assessment, agriculture also requires a tool that provides data integration ability, transparency, robust analysis, engaging stakeholders' opinions, and improved learning. MCDA methods can be easily applied to agricultural sustainability assessment because they are structured and transparent, can break down complex problems, facilitate discussion, and produce a systematic and visual presentation of the perspectives of diverse stakeholders [44-46]. MCDA is appropriate for assessing complex agricultural sustainability problems because it can integrate the interests and objectives of sustainability pillars through criteria and weight factors [47]. In this research, the PROMETHEE approach to MCDA is utilized to rank six agricultural systems in coastal Bangladesh. However, other MCDA approaches having different decision rules for ordering the alternatives according to various sustainability criteria could be used, such as the elimination method [48] and MAUT [49], which have previously been applied to the same agricultural systems studied in this paper. Moreover, other techniques for assessing the sustainability of agricultural practices could be utilized, such as in References [50-53].

\section{Brief Review of the PROMETHEE Method}

In order to fully appreciate the scientific aspect of the outputs from PROMETHEE in terms of outcomes regarding the problem being studied, one must understand the operational side of PROMETHEE. PROMETHEE was developed by Brans in 1982 [42]. It is a pair-wise comparison-based outranking methodology to evaluate and compare a finite set of alternatives in terms of multiple criteria [54]. The PROMETHEE consist of PROMETHEE I for partial ranking, PROMETHEE II for complete ranking from the best to the worst of a fixed set of possible alternatives, and PROMETHEE GAIA for visualizing the results [55]. PROMETHEE II with GAIA, also known as PROMETHEE-GAIA [55], is used in this paper. The PROMETHEE II-GAIA methodology is better than other methods for the purposes of this paper as it provides a complete ranking of alternatives. In GAIA, a clear graphical representation of alternatives and their values can be seen. GAIA is able to show the best alternative as well as represent the criteria that identify the best alternatives and provide a graphical presentation of the sensitivity analysis [56]. For more details about the PROMETHEE-GAIA methodology, Brans and Mareschal [57] and the PROMETHEE 1.4 Manual [56] can be consulted. 
The alternatives in PROMETHEE II are evaluated according to the maximum or minimum values of the criteria. The weighting of the criteria and the preference function of the criteria are two important elements of PROMETHEE II [56]. PROMETHEE does not offer particular guidelines for determining weights for criteria, but it is assumed that the decision-maker is able to weight the criteria appropriately. Weighting is thus influenced by the skills of the decision maker [58], at least when the number of criteria is not too large [59]. Each weighting remains subjective and is restricted only to the evaluated alternatives. Therefore, sensitivity analyses, which clarify how far the chosen weights influence the output, become important [60]. It is also vital to be transparent and clear so the results can be fully understood and replicated as needed. The sum of the weighting is 1 . The preference functions of PROMETHEE for each criterion reflect the intensity of preference of one alternative over another. Values of the preference function are between 0 and 1 [61]. For pairwise comparisons, six specific types of generalized preference functions are suggested [62], as illustrated in Table A1 in the Appendix A.

Figure 1 presents the steps for the PROMETHEE procedure. The procedure usually begins by identifying the alternatives $(a, b)$ and associated criteria $\left(f_{j}\right)$. The deviations of the criteria $\left(f_{j}\right)$ of alternatives $(a, b)$ are determined based on pair-wise comparisons in step two. Next, a relevant preference function for each criterion is determined. The fourth step is to calculate the global preference index. Fifth, the positive and negative outranking flows are calculated for each alternative. Net outranking flow for each alternative and complete ranking takes place in step six. The final step is a sensitivity analysis of the weighting and the calculation of the complete final ranking. A detailed guideline of the procedure of PROMETHEE can be found in the PROMETHEE 1.4 Manual [56].

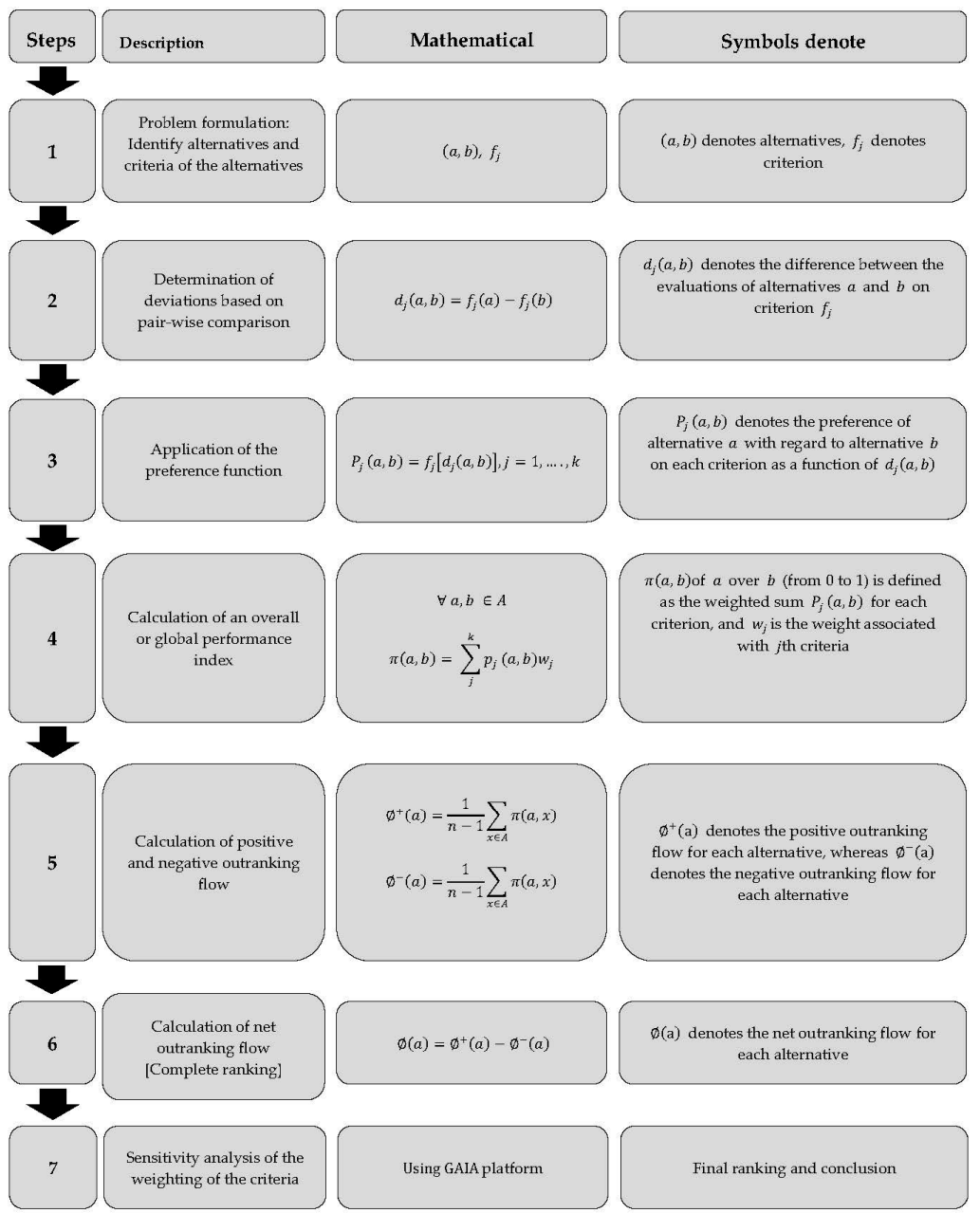

Figure 1. The general steps of the procedure of PROMETHEE. Source: Adapted and modified from Behzadian et al. [42] and PROMETHEE 1.4 Manual [56]. 


\section{Data and Methodological Approach for the Case Study}

\subsection{Agricultural Sustainability Assessment Methodology Based on PROMETHEE}

Agricultural sustainability assessment methodology based on PROMETHEE is illustrated in Figure 2. To perform the analysis, the Visual PROMETHEE 1.4 Academic Edition software (B. Mareschal, Bruxelles, Belgium) was selected as it is freely accessible for students and has a wider application in natural resources applications.

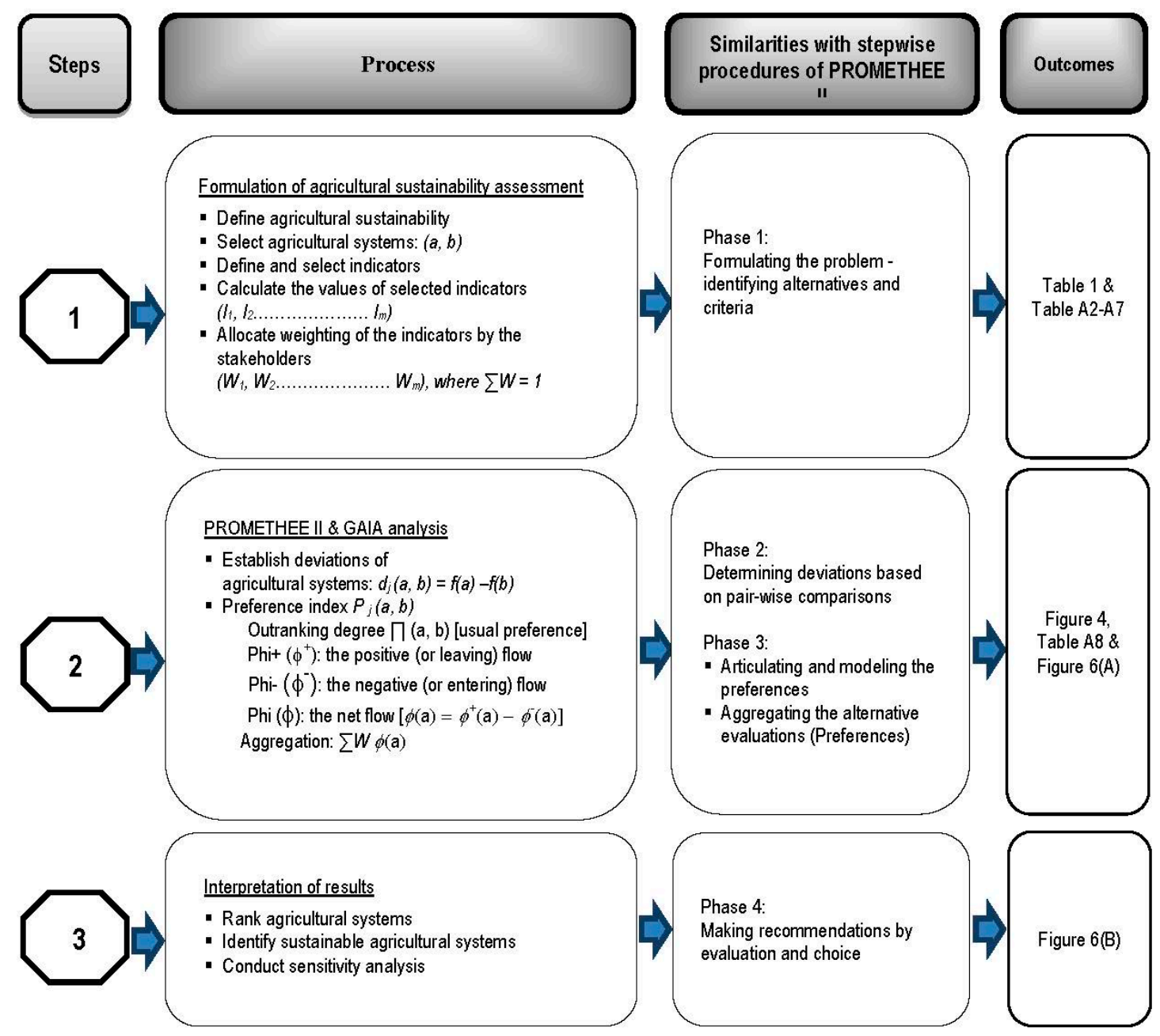

Figure 2. The PROMETHEE steps for agricultural sustainability assessment, developed from the ideas of the general steps (Figure 1) of the procedure of PROMETHEE and MCDA. Source: Based on the PROMETHEE 1.4 Manual [56].

First, the agricultural systems to be assessed were identified. Following the first step of MCDA and PROMETHEE (Problem formulation), agricultural sustainability was defined as human activities to produce food and fiber in a manner that ensures the well-being of the present and future community without diminishing the surrounding ecosystems' capacity and ensuring environmental integrity, social well-being, resilient local economies, and effective governance [63-65]. This definition helps to identify the indicators and the indicator values of agricultural systems. Positive values of the criteria indicate a better sustainability, which means the higher the value of the criteria, the more sustainability is achieved; therefore, all the criteria are set as a maximized preference function. Due to the qualitative character of the criteria, the usual criterion function was used because it has no threshold. Here, the stakeholders' weighting (Table 1) for the indicator was used as criteria weighting. 
In the second step, the deviations of the indicators of the agricultural systems are determined by pairwise comparisons. From these deviations, the preference indexes are calculated and then the net flow of the preferences is calculated based on the positive (or leaving) flow and negative (or entering) flow. Subsequently, the aggregate rankings are calculated by using weighting and the net flow of the preferences (see step 2 of Figure 2). In the third step, the most sustainable alternatives (i.e., sustainable agriculture systems) are identified from the aggregate rankings. To investigate the impacts of weighting, a sensitivity analysis is carried out and from these results, the most sustainable agriculture system in terms of the selected criteria can be recommended.

\subsection{Data for the Case Study}

The proposed methodological approach was tested by using the data collected from five agricultural systems: Bagda (shrimp)-based agricultural systems (S) from Shyamnagar Upazila (Upazila is the second lowest tier of regional administration in Bangladesh [66]); Bagda-rice-based agricultural systems (SR) from Kalijang Upazila; rice-based agricultural systems (R) from Kalaroa Upazila; Galda-rice-vegetable-based integrated agricultural systems (I) from Dumuria Upazila; and traditional practices-based agricultural systems (T) from Bhola Sadar Upazila. These Upazilas are located in the southwest coastal zone of Bangladesh (see Figure 3). In the Bagda-based agriculture system, shrimp with some rice is produced; Bagda-rice-based agricultural systems only produce shrimp and rice when the salinity is low; rice-based agricultural systems in which rice is intensely cultivated; Galda-rice-vegetable-based integrated agricultural systems produce shrimp, fish, rice, and vegetables whereas traditional practices-based agricultural systems cultivate rice throughout the year. The data for these agricultural systems were tabulated and refined by Talukder [67] based on issues related to six categories of agricultural sustainability: productivity, stability, efficiency, durability, compatibility, and equity. In brief, productivity represents the yield of agricultural systems. Stability indicates the capacity of the agricultural system to maintain a good productivity. Efficiency is related to the use of resources. Durability means the resistance of the agricultural systems against any shock. In a broad sense, compatibility indicates the coping capacity of the agricultural systems with the bio-geophysical, human and socio-cultural surroundings. The equity is related to the quality of life the farmers and their family members [65].

In Talukder [67], the data related to these six categories of sustainability came from both primary and secondary sources. Secondary data were collected from a literature survey and published government documents like the Upazila soil profile reports released by the Bangladesh Soil Research Institute. Primary data were collected through field observation, formal and informal questionnaire surveys, interviews, and focus group discussions with different stakeholders. The stakeholders were selected from farmers, key informants, agriculture extension officers, fisheries officers, livestock officers, block supervisors, and local villagers who directly or indirectly influence the selected agricultural systems. Randomly selected representatives from a total of 221 households in five categories of farmers (Landless ( $<0.01$ acres), marginal ( $0.01 \leq 0.50$ acres), small ( $0.50 \leq 2.5$ acres), medium ( $2.5 \leq 5.0$ acres) and large ( $>5.0$ acres) [68]) answered a questionnaire survey for primary data collection. 


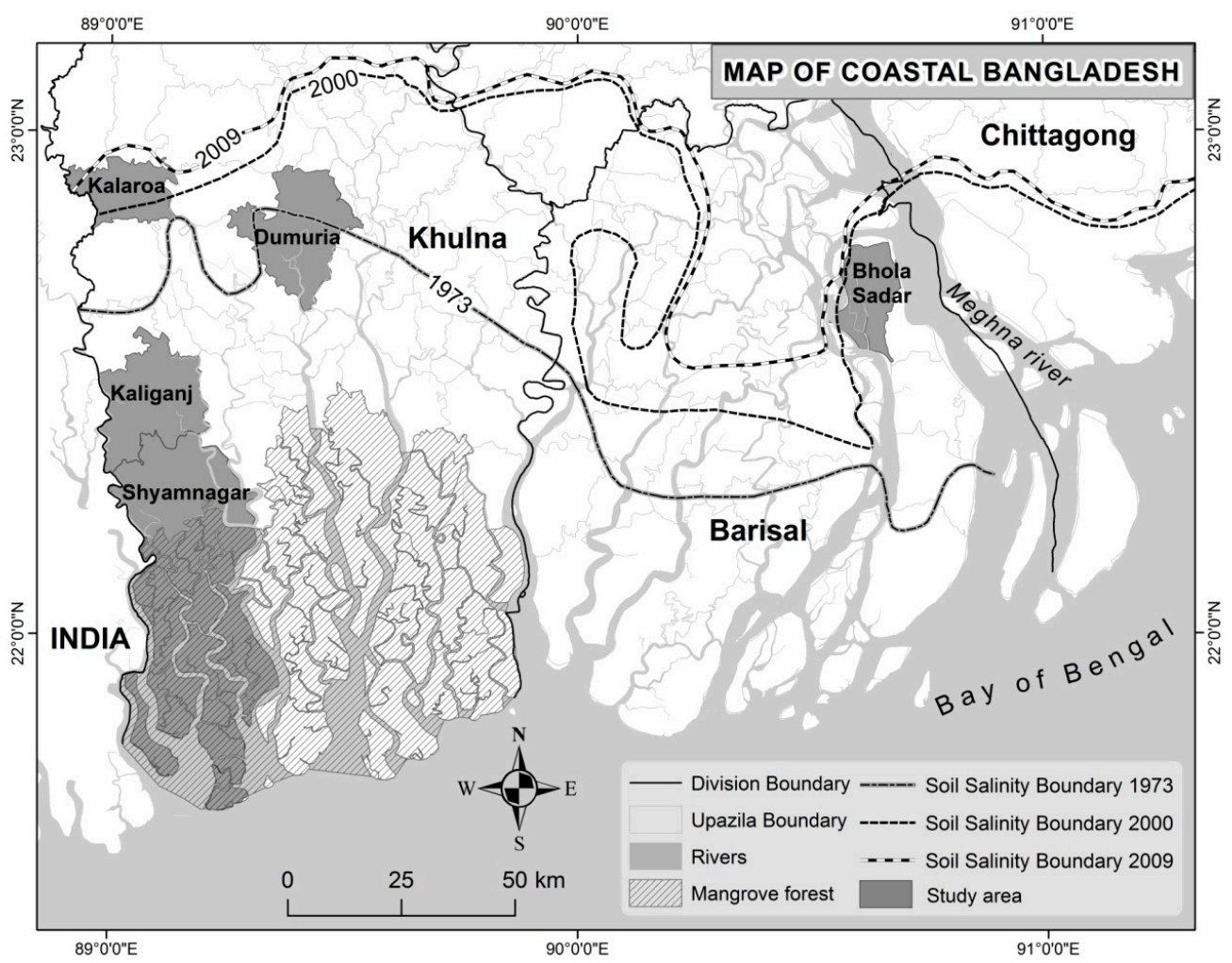

Figure 3. The "location of the study areas and gradients of soil salinity (1973-2009) in the coastal zone of Bangladesh. The soil salinity contours represent the northern boundary of areas where soils may have salinity values of $2 \mathrm{dS} / \mathrm{m}$ or more" ([16] p. 149).

Table 1. The composite indicators, their values, and weighting.

\begin{tabular}{|c|c|c|c|c|c|c|c|c|}
\hline \multirow{2}{*}{ Sustainability Category (SC) } & \multirow{2}{*}{ Composite Indicators (CI) } & \multicolumn{2}{|c|}{ Weighting * } & \multicolumn{5}{|c|}{ Agricultural Systems } \\
\hline & & SC & CI & $\mathrm{s}$ & SR & $\mathbf{R}$ & I & $\mathbf{T}$ \\
\hline Productivity $(\mathrm{P})$ & Productivity (Pro) & 20 & - & 0.07 & 0.16 & 0.30 & 0.30 & 0.14 \\
\hline \multirow{3}{*}{ Stability (S) } & Landscape stability (LS) & \multirow{3}{*}{20} & 5 & 0.14 & 0.18 & 0.20 & 0.21 & 0.22 \\
\hline & Soil health/stability (SH/S) & & 10 & 0.15 & 0.21 & 0.21 & 0.15 & 0.22 \\
\hline & Water quality (WQ) & & 5 & 0.11 & 0.18 & 0.18 & 0.22 & 0.29 \\
\hline \multirow{2}{*}{ Efficiency (E) } & Monetary efficiency (ME) & \multirow{2}{*}{15} & 5 & 0.10 & 0.14 & 0.18 & 0.43 & 0.15 \\
\hline & Energy efficiency (EE) & & 10 & 0.07 & 0.16 & 0.30 & 0.30 & 0.14 \\
\hline \multirow{3}{*}{ Durability (D) } & Resistance to pest stress (RTPS) & \multirow{3}{*}{15} & 5 & 0.24 & 0.27 & 0.19 & 0.18 & 0.12 \\
\hline & Resistance to economic stress (RTES) & & 5 & 0.25 & 0.20 & 0.19 & 0.20 & 0.17 \\
\hline & Resistance to climate change (RTCC) & & 5 & 0.22 & 0.27 & 0.11 & 0.30 & 0.10 \\
\hline \multirow{2}{*}{ Compatibility $(\mathrm{C})$} & Human compatibility (HC) & \multirow[b]{2}{*}{10} & 5 & 0.06 & 0.22 & 0.24 & 0.25 & 0.24 \\
\hline & Biophysical compatibility (BC) & & 5 & 0.10 & 0.13 & 0.29 & 0.22 & 0.27 \\
\hline \multirow{4}{*}{ Equity (E) } & Education $(\mathrm{Edu})$ & \multirow{4}{*}{20} & 5 & 0.20 & 0.22 & 0.20 & 0.26 & 0.12 \\
\hline & Economic (Eco) & & 5 & 0.17 & 0.23 & 0.21 & 0.22 & 0.17 \\
\hline & Health (Hlth) & & 5 & 0.17 & 0.21 & 0.18 & 0.26 & 0.18 \\
\hline & Gender (Gen) & & 5 & 0.17 & 0.19 & 0.26 & 0.32 & 0.06 \\
\hline
\end{tabular}

Source: [67]. Note ${ }^{*}$ Total weight $=100$.

From the data set, 15 single composite indicators (see Table 1) were developed from a total of 50 indicators (Tables A2-A7) by using proportionate normalization and the hybrid aggregation technique. In proportionate normalization a "single attribute value is divided by the sum total of the values of attributes" ([69] p. 7), whereas hybrid aggregation was carried out by using the arithmetic and geometric mean. These 15 single composite indicators create a set of representative criteria of the sustainability of the five selected agricultural systems. To assign weighting values to the sustainability categories (see Table 1), experts, key informants, and farmers were asked to give their opinions regarding the relative importance of the categories and their average opinion was taken into account 
in assigning the weighting. Considering the situation of coastal Bangladesh and the importance of food security, productivity is given the highest weight, followed by soil stability and energy efficiency. Other criteria are given the same weighting.

As can be seen in Table 1, productivity is highest in rice-based agricultural systems (R) and integrated agricultural systems (I). The scores of other composite indicators are also good in " $\mathrm{I}$ " compared to other agricultural systems. Farmers of "I" use integrated agriculture with rice, shrimp and vegetables, whereas in " $\mathrm{R}$ " rice is the dominant crop among many diverse crops. "SR" produces rice and shrimp, whereas Shrimp (" $\mathrm{S}$ ") is focused on massive shrimp cultivation with limited rice. " $\mathrm{T}$ " is traditional rice cultivation with other associated crops.

\section{Results of the Application of PROMETHEE for Agricultural Sustainability Assessment}

The action profiles deployed in Figure 4, as well as Table A8 in the Appendix A, show the disaggregated view of the strengths and weaknesses of the alternatives based on the inserted values of the criteria. The action profiles are a graphical representation of the net flow scores for the criteria (composite indicators) listed in the categories of the five agricultural systems in Table 1. For each alternative, upward bars (positive scores) correspond to preferred features, while downward bars (negative scores) link to negative ones. For example, in "I", only the SH/S (Soil health/stability) and RTPS (Resistance to pest stress) criteria have negative scores; all other criteria have positive scores.

In "R", the WQ (Water quality), RTPS, RTES (Resistance to economic stress), and RTCC (Resistance to climate change) criteria have negative scores. This action profile demonstrates that " $\mathrm{I}$ " is doing well, followed by " $\mathrm{R}$ ", "SR", "T" and " $\mathrm{S}$ " with respect to the decision criteria. " $\mathrm{S}$ " is doing well only in RTPS and RTCC. An interesting observation that can be made from Figure 4 is that "SR" and "S" have a good durability score, which is supported by the existence of certain features related to durability like improved availability of seed due to government support, less use of pesticide due to shrimp cultivation and better climate awareness after the cyclone Aila event in 2009 [67].

The results of the final ranking and network of alternative flow are obtained, and their values are illustrated in Figure 5A,B. Figure 5A represents the final rank of alternatives based on the net flow of the alternatives, whereas Figure $5 \mathrm{~B}$ represents the final score of the positive and negative flow of the alternatives. This ranking gives an overview of all alternatives, including their preference scores. The ranking score is the final score of the net preference flow of the PROMETHEE analysis combining weights, preference functions and values for the criteria per alternative. Among the alternatives, "I" (0.54) is first in terms of sustainability on the rank list, while " $\mathrm{S}$ " and " $\mathrm{T}$ " were the lowest ranked -0.66 and -0.2 , respectively. The higher weight on the productivity criteria increased the ranking score of " $\mathrm{I}$ " and "R" since they both have a good productivity score.

The results of this case study indicate that " $\mathrm{I}$ " has a higher level of agricultural sustainability compared to "R", "SR", "T", and "S" and is characterized by positive scores for all categories of sustainability. For example, productivity is high in " $\mathrm{I}$ ". This is consistent with the findings of Rahman and Barmon [70], who also found that productivity was good in integrated agricultural systems and positive for overall agricultural sustainability. Similar results were determined in a previous analysis of these Bangladeshi agricultural systems that utilized an energy analysis to evaluate environmental sustainability [16]. In the action profile, energy use efficiency in " $\mathrm{I}$ " and " $\mathrm{R}$ " is better than in "SR", " $\mathrm{T}$ ", and " $\mathrm{S}$ ", indicating better environmental performance in integrated and rice-based agricultural systems because energy efficiency is one of the measures of environmental sustainability. One of the reasons for the increased energy efficiency may be that the integrated and rice-based agricultural systems are supported by diverse crops. This case study reviews and allows the comparisons of the agricultural sustainability of the five agricultural systems. From the analysis based on selected criteria, it appears that "I" is more sustainable than mono-culture type agricultural systems such as shrimp-only production systems. This finding can be helpful for the implementation of sustainable agriculture in coastal Bangladesh. 

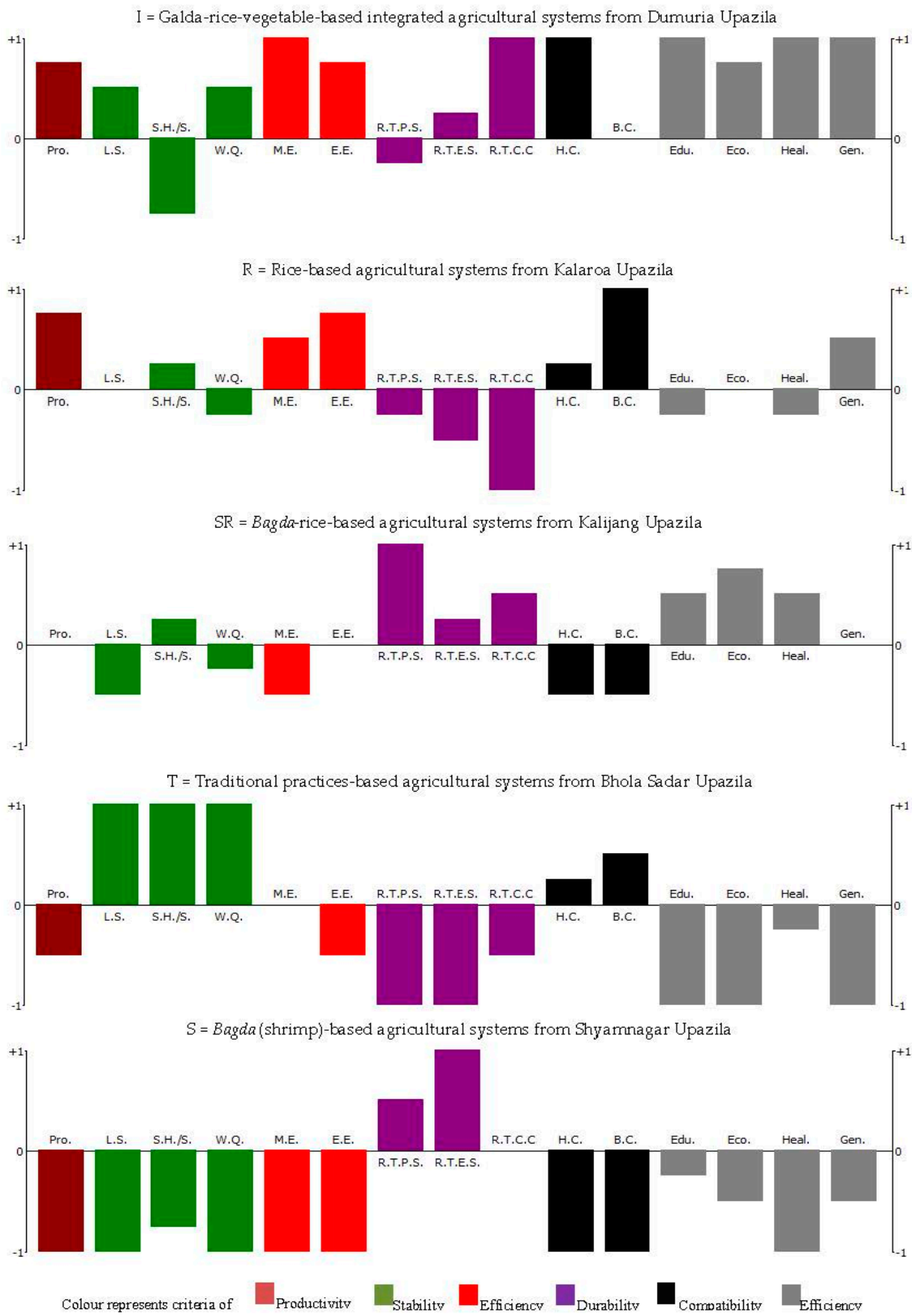

Figure 4. The comparison of uni-criteria net flow scores of criteria of the agricultural systems. Results generated by PROMETHEE-GAIA software. Note: Pro = Productivity; LS = Landscape stability, $\mathrm{SH} / \mathrm{S}=$ Soil health/stability; $\mathrm{WQ}=$ Water quality; $\mathrm{ME}=$ Monitory efficiency; EE = Economic efficiency; RTPS = Resistance to pest stress; RTES = Resistance to economic stress; RTCC $=$ Resistance to climate change; $\mathrm{HC}=$ Human compatibility; $\mathrm{BC}=$ Biophysical compatibility; Edu = Education; Eco = Economic; Heal $=$ Health; Gen = Gender. Source: The results were generated by the PROMETHEE-GAIA software. 

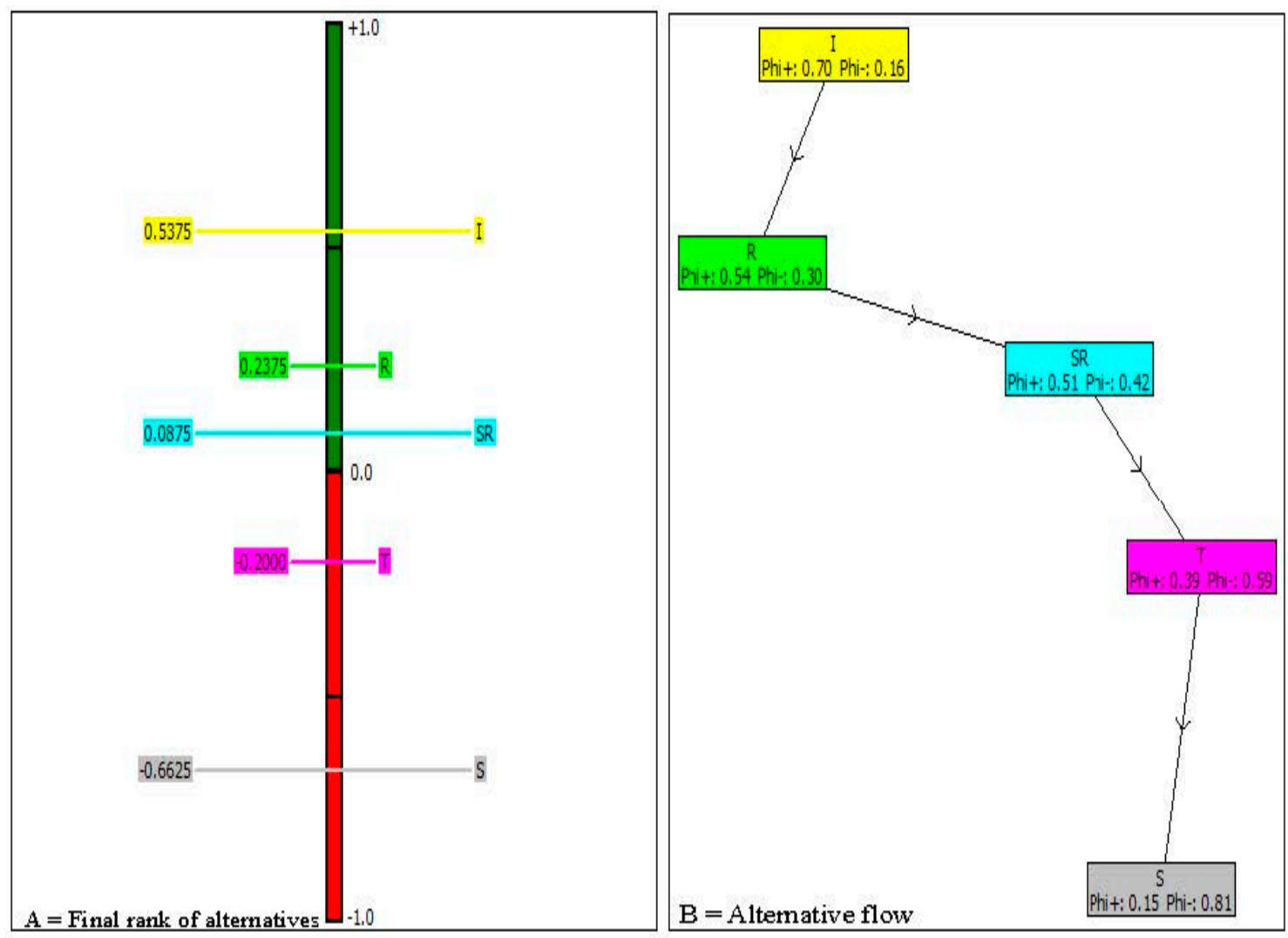

Figure 5. The overall ranking (A) and alternatives flow (B) considering criteria values and weighting. The result generated were by the PROMETHEE-GAIA software.

\section{Sensitivity Analysis in PROMETHEE to Assess Agricultural Sustainability}

It is clear that the outranking results are influenced by the weights allocated to the criteria, so it is important to know how the ranking changes when the weights change. Therefore, using a special feature of the software called "walking weights", a sensitivity analysis was carried out to verify how sensitive the results are when the weights change (Figure 6). The walking weights feature of the Visual PROMETHEE 1.4 Academic Edition software allows the weights of a particular criterion to be increased while proportionately decreasing the weights of the other criteria. When the criteria were given an equal weight, sensitivity analysis showed that the ranking of the five alternatives is rather stable as displayed in Figure 6 . The weight of productivity was increased by $50 \%$ and no change was found in the rankings, but the rankings of the agricultural systems varied when the weights of other criteria were changed by different percentages. Nevertheless, the position of " $\mathrm{I}$ " remained the same in each case. From this analysis, it is clear that most of the criteria (and their weights) do not influence the final ranking. 

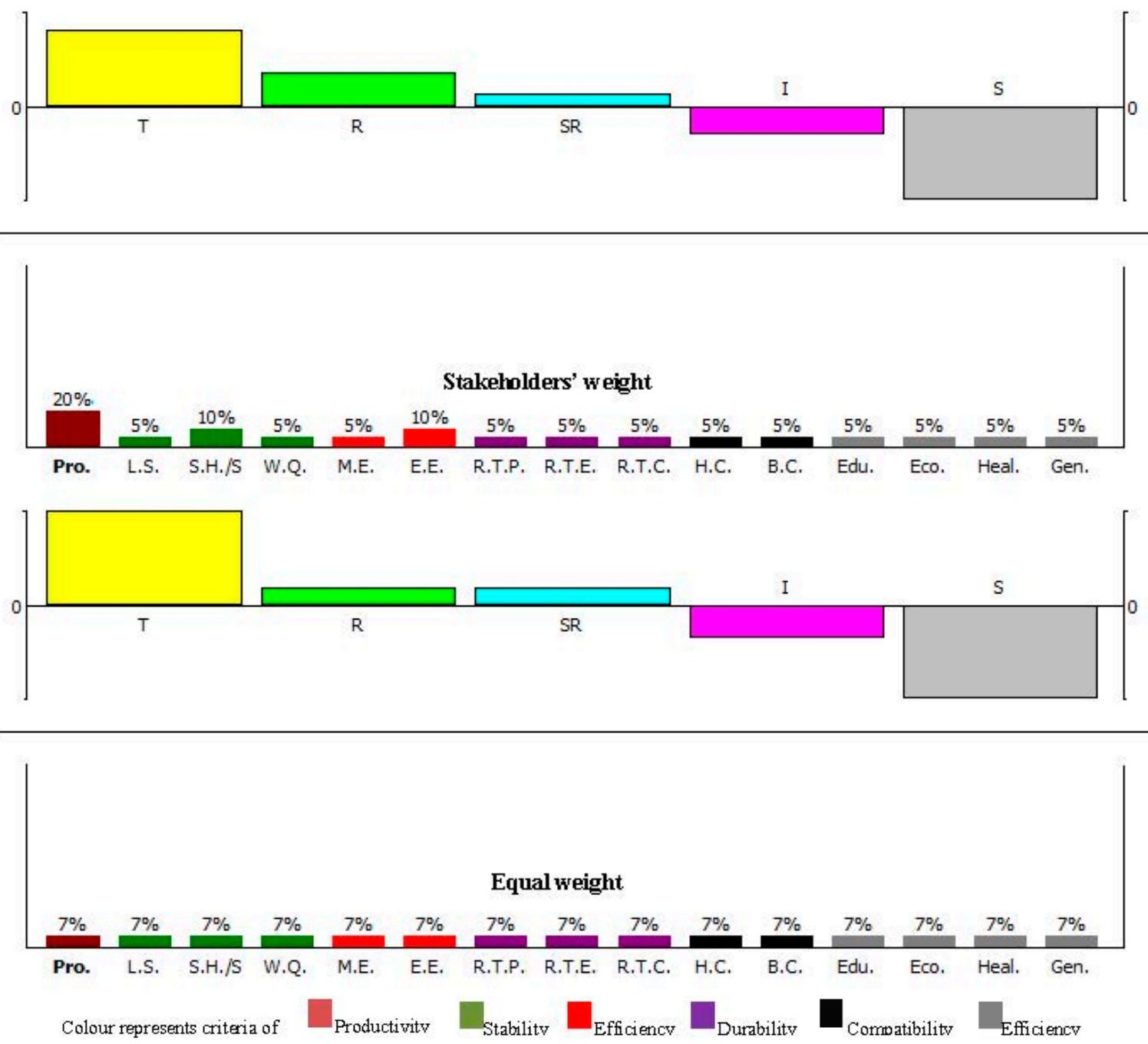

Figure 6. The Walking Weight (sensible score analysis) used for sensitivity analysis. Results were generated by the PROMETHEE-GAIA software. Top and bottom analyses show the ranking of the agricultural systems after considering the stakeholders' weight and equal weight.

\section{Discussion of the Results of the PROMETHEE Application}

This methodology calculates the relative rankings and levels of sustainability by comparing different agricultural systems and also indicates the weak and strong sustainability criteria of the different agricultural systems within the total values of the indicators. As agricultural sustainability depends on complex considerations, the assessment should consider multiple criteria. The PROMETHEE system is very robust as it has the capability to consider multiple criteria in assessing the final sustainability ranking as well as comparing the criteria. It also facilitates an understanding of the positive and negative roles of different criteria for final additive ranking. The net flow graph in Figure 4 helps to visualize the strengths and weaknesses of the criteria [71]. From the results displayed in Figure 4 and the findings listed in Table A8, the overall best alternative is the integrated agricultural systems (I), as explained in Section 5. As the final sustainability ranking of the alternatives critically depends on the criteria values and weighting assumptions, the criteria information should be as precise and appropriate as possible [72]. While the selection of essential criteria for agricultural sustainability is challenging [73], this study shows that by using a set of multiple criteria, PROMETHEE makes it possible to rank the sustainability of different agricultural systems as well as to analyze and compare a large amount of information. 
A further advantage is that the PROMETHEE-based methodological approach takes into consideration all the multiple criteria holistically through pairwise comparisons, which most of the existing frameworks for agricultural sustainability assessments have failed to do [11]. It also aggregates the preference values into an individual additive score. The proposed framework evaluation shows that PROMETHEE is capable of handling a holistic set of indicators and ranking the level of sustainability of agricultural systems, making it suitable for the agricultural system sustainability assessment. Criteria with different scales can be handled by this method and it can generate a complete ranking of the sustainability of agricultural systems from best to worst [54]. This method is also capable of using the weighting generated by participatory processes [29]. It allows for a graphic representation of the criteria using GAIA, which provides a better understanding of the inter-dimensional interactions and conflicts of the criteria of agricultural sustainability, thereby facilitating learning, debate, and consensus building among the stakeholders. As demonstrated in Figure 5, it can also be utilized to carry out fairly robust sensitivity analyses.

In spite of these advantages, this approach comes with limitations. The application of this methodology requires the simplification of some functions of PROMETHEE. For example, setting preferences for the agricultural sustainability criteria is difficult since all criteria are important. Given this challenge, the values of the criteria were developed to show that the higher values of the criteria are the "best" in terms of sustainability. Therefore, the usual preference functions of the criteria were considered rather than utilizing the threshold values preference function. However, determining the thresholds of different criteria of agricultural sustainability is difficult since agricultural sustainability is relative and influenced by social, economic, and environmental factors [15]. That said, this adaptation of the PROMETHEE assessment tool is a positive step in understanding and comparing multiple dimensions of sustainability.

Another drawback is that the calculation of preference information in PROMETHEE can be a fairly complicated process and may be hard for a non-expert or a practitioner to use or understand it at a glance. The rather complex calculation process of the final ranking and the difficult interpretation of the ranking and other results may be a limitation of PROMETHEE from a practical application point of view [56]. Moreover, like MAUT-based MCDA, PROMETHEE does not provide the possibility to really structure a sustainability problem [74]. This limitation may prevent users from understanding issues and concerns related to sustainability problems. Hence, a goal for PROMETHEE developers could be to make their program more widely relevant.

Another limitation is that PROMETHEE does not provide any formal guidelines for the weighting of the criteria. Rather, it depends on the capabilities of decision-makers and assumes that the decision makers are able to weigh the criteria appropriately. To understand the various weighting methods for the criteria, OECD [75] documents can be consulted. When there are many criteria, the weighting becomes even more challenging. Many criteria may make it difficult to create a clear view of the alternatives and evaluate the results. Nevertheless, in general, the transparency of PROMETHEE is relatively high. This method also has a non-compensatory rationality and the meaning of the criteria weights is related to the degree of their relative importance [76].

The case study used in this paper facilitates comparisons of the sustainability of five different agricultural systems. From this case study, it appears that integrated agricultural systems are the best in terms of the selected sustainability criteria. This finding can be used to formulate an evidence-based policy promoting the implementation of this system as a way to increase the sustainability of agriculture in coastal Bangladesh. Ranking agricultural systems using a PROMETHEE-based framework can provide guidance for local agricultural offices, for agricultural extension workers to assist farmers, as well as for farmers to act in more structured and strategic ways for sustainable agricultural planning and programming. For example, the indicators (criteria) and final results can help decision makers to understand the importance of different indicators. From the performance of the criteria (indicators) in an overall ranking, the local agricultural offices, agricultural extension workers and farmers can make 
more informed decisions about what initiatives they should utilize to make unsustainable agriculture more sustainable.

The results of the assessment provide diagnostic information regarding productivity, efficiency, stability, durability, compatibility, and equity to local agricultural offices, agricultural extension workers, and farmers that will help them understand the problems and prospects of utilizing different agricultural systems in terms of sustainability. This research presents a set of sustainability issues for local officials and farmers that need further investigation. For instance, coastal communities in Bangladesh practice a type of agriculture that creates impacts particularly in the context of ecological degradation, climate change, and population increase. The sustainability of coastal agriculture is very significant for future adaptation and sustainability planning, and the findings from this research help to identify fairly sustainable outcomes. Sustainability rankings can sound a warning about the sustainable performance of agricultural systems that will help local agricultural offices, agricultural extension workers and farmers to take appropriate actions to ensure the sustainability of the agriculture of coastal Bangladesh and elsewhere. For example, by understanding the environmental, economic and social problems of shrimp cultivation, local agricultural offices and extension workers can raise awareness among local farmers about the negative effects of shrimp farming and suggest that they convert their agriculture to integrated agricultural systems since these are adaptive and show enhanced performance in terms of sustainability. From this assessment, by looking at the performance of each criterion (indicator) in terms of social, economic, and environmental issues of agricultural systems, the practitioner or researcher can make decisions about which criterion (indicator) needs improvement or which agricultural system should be promoted for the sustainability of the agricultural systems in coastal areas.

The Asian Development Bank (ADB), International Union for Conservation of Nature (IUCN), Food and Agriculture Organization of the United Nations (FAO), and United Nations Development Programme (UNDP) have developed and used sustainability assessment methodologies. In Bangladesh, the Poverty Reduction Strategy Paper (PRSP), Millennium Development Goals (MDGs) and National Sustainable Development Strategy (NSDS) urged sustainability assessments. Recently, the United Nations (UN) introduced indicator (criterion) based sustainable development goals (SDGs), which include a call for "a robust follow-up and review mechanism for the implementation of the new 2030 Agenda for Sustainable Development [that] will require a solid framework of criteria (indicators) and statistical data to monitor progress, inform policy and ensure accountability of all stakeholders" ([77] p. 1). This important process offers the possibility of develop in a meaningful approach so that the "design and implementation of a solid framework of criteria (indicators) will provide meaningful and reliable information to ensure a sustainable future with lives in dignity for all" ([77] p. 1).

SDG frameworks will need to integrate social, economic and environmental criteria (indicators) and provide guidance for humanity to prosper in the long term [78]. The MCDA-based assessment framework that is proposed and tested in this paper has the capacity to integrate indicators and could be a methodological option or template for monitoring and comparing the unified progress of the SDGs [78]. However, these outcomes would require a test case to see if the proposed framework is appropriate for monitoring and comparing SDGs among countries. To monitor the progress of SDGs within and among countries, combinations of the sustainability indicators under the seventeen goals could be converted into a composite indicator by using PROMETHEE-based assessment frameworks. PROMETHEE could provide rankings and comparisons of SDGs through pairwise comparisons of the indicators.

\section{Conclusions}

To the authors' knowledge, this is the first time an attempt has been made to assess and compare agricultural sustainability by employing PROMETHEE. The results of this study show that with some limitations this approach is useful to assess agricultural sustainability. The framework presented here can enable decision makers and analysts to provide methodological advice for agricultural 
sustainability assessments. In this paper, a multi-criteria-based holistic approach is used for assessing the sustainability of agricultural systems. The results of the analysis demonstrate that this method has the capacity to be a useful framework for ranking agricultural systems and making decisions about their sustainability.

Here, the PROMETHEE-based sustainability assessment framework provides systematic guiding principles which can be utilized for sustainability assessment of other agricultural systems and other sectors like organic farming, urban agriculture, agroforestry, poultry farming, dairy farming, supply chain management, wetland management, water management, green energy management, and corporate sustainability assessment, among others. FAO [63] noted that considering sustainability dimensions as a coherent whole remains a major challenge in sustainability assessments, but it can be solved if agricultural sustainability is assessed using appropriate PROMETHEE-based frameworks, as these methods allow for the incorporation of indicators from the social, economic, and environmental dimensions of sustainability to generate overall scores which can represent a range of sustainability considerations. PROMETHEE-based sustainability assessments are capable of bringing all of the social, economic, and environment indicators together and assessing sustainability in a holistic way.

Author Contributions: B.T. envisioned and designed the original research as part of his Ph.D. Thesis. K.W.H. helped to execute the research.

Funding: This paper was supported by the Social Sciences and Humanities Research Council (SSHRC), Canada as well as by a Discovery Grant from the Natural Sciences and Engineering Research Council (NSERC) of Canada.

Acknowledgments: The authors would like to express their appreciation to the anonymous referees for their thoughtful suggestions for improving the quality of their paper. They would also like to thank Sheila Hipel for her editing of their paper.

Conflicts of Interest: The authors declare no conflict of interest. 


\section{Appendix A}

Table A1. The preference functions in PROMETHEE.

\begin{tabular}{|c|c|c|c|}
\hline Type of Preference & Description of the Preference & Graphical Presentation & Analytical Definition \\
\hline I: True/Usual criterion & $\begin{array}{l}\text { When the value of the criteria of alternative } a \text { exceeds alternative } b \text {, then there is a } \\
\text { strict preference and the preference value is } 1 \text {. In case of equal value of the criteria, } \\
\text { there is no preference and the preference value is } 0 \text {. }\end{array}$ & Non-decreasing & $f(d)=\left\{\begin{array}{l}1 \text { if } 0<d \\
0 \text { if } d \leq 0\end{array}\right.$ \\
\hline II: Threshold criterion & $\begin{array}{l}\text { The decision maker defines the indifference threshold value of the criteria. If the } \\
\text { value of the criteria of alternative a exceeds that of alternative } b \text { by an amount } q \text {, } \\
\text { greater than or equal to the indifference value }(q) \text {, then a is preferred over } b \text {. }\end{array}$ & Non-decreasing & $f(d)=\left\{\begin{array}{l}1 \text { if } q<d \\
0 \text { if } d \leq q\end{array}\right.$ \\
\hline III: Linear with threshold criterion & $\begin{array}{l}\text { If the criteria value of alternative } a \text { is closer to the absolute preference than } \\
\text { alternative } b \text {, then alternative } a \text { is better than alternative } b \text {. If the difference of the } \\
\text { criteria of alternative } a \text { reaches the absolute preference, then alternative } a \text { is } \\
\text { absolutely better than alternative } b \text {. }\end{array}$ & Nor-dec & $f(d)=\left\{\begin{array}{rr}1 & \text { if } p<d \\
\frac{d}{p} & \text { if } 0<d \leq p \\
0 & \text { if } d \leq 0\end{array}\right.$ \\
\hline IV: Linear over range criterion & $\begin{array}{l}\text { First, an indifference value of the criteria is determined. When the difference of } \\
\text { the criteria values of alternatives } a \text { and } b \text { moves from a value } 0 \text { to a value } p \text {, } \\
\text { the preference function increases linearly from } 0 \text { to } 1 \text { over that range of } \\
\text { differences. If the criteria value of alternative } a \text { passes the difference of the } \\
\text { threshold value of } 0 \text {, then } a \text { is preferred to } b \text {. }\end{array}$ & $\begin{array}{r}\text { Non-decreasing } 1 \\
1 / 2 \\
0\end{array}$ & $f(d)=\left\{\begin{array}{cc}1 & \text { if } p<d \\
\frac{d-q}{p-q} & \text { if } q<d \leq p \\
0 & \text { if } d \leq q\end{array}\right.$ \\
\hline V: Stair step/Level criterion & $\begin{array}{l}\text { For this method, an absolute preference value and an indifference value are } \\
\text { determined. If the criteria value of alternative } a \text { is less than the absolute } \\
\text { preference value that gives a preference of } 0 \text {, the difference between the absolute } \\
\text { preference value and indifference value gives a preference of } 1 / 2 \text {, and a difference } \\
\text { greater than the absolute preference value gives a preference of } 1 \text {. }\end{array}$ & Non-decreasing & $f(d)=\left\{\begin{array}{rr}1 & \text { if } d>p \\
\frac{1}{2} & \text { if } q<d \leq p \\
0 & \text { if } d \leq q\end{array}\right.$ \\
\hline VI: Gaussian criterion & $\begin{array}{l}\text { The } s \text { threshold value is somewhere between the } q_{j} \text { indifference threshold and the } \\
q_{j} \text { preference threshold and it follows a normal distribution. This preference } \\
\text { function is less often used due to the difficulty in the parameters. }\end{array}$ & Non-decreasing ${ }^{\dagger}$ & $f(d)= \begin{cases}1-\exp \left(\frac{-d^{2}}{2 \sigma^{2}}\right) & \text { if } 0<d \\
0 & \text { if } d \leq 0\end{cases}$ \\
\hline
\end{tabular}

Legend: $d=$ the difference between two criteria $a$ and $b, p=$ the strict preference threshold, $q=$ the indifference threshold, $s=$ the standard deviation in Gaussian distribution. Source: Based on Diakoulaki and Koumoutsos ([67] p. 1). 
Table A2. The selected indicators and values to construct single composite indicators for productivity.

\begin{tabular}{|c|c|c|c|c|c|c|c|c|c|c|c|}
\hline \multirow{2}{*}{$\begin{array}{l}\text { Sustainability } \\
\text { Category }\end{array}$} & \multirow{2}{*}{$\begin{array}{l}\text { Composite } \\
\text { Indicator }\end{array}$} & \multirow[b]{2}{*}{ Indicators } & \multirow{2}{*}{ Unit } & \multirow{2}{*}{ Data Type } & \multirow{2}{*}{$\begin{array}{l}\text { Sustainability } \\
\text { Pillar }\end{array}$} & \multirow{2}{*}{$\begin{array}{l}\text { Data } \\
\text { Source }\end{array}$} & \multicolumn{5}{|c|}{ Agricultural Systems } \\
\hline & & & & & & & $S$ & SR & $\mathbf{R}$ & I & $\mathrm{T}$ \\
\hline \multirow{3}{*}{ Productivity } & \multirow{3}{*}{ Productivity } & Weighted yield of the main staple crop & t/ha & QTL & Economic & Q.S. & 2.26 & 4.41 & 5.23 & 6.51 & 2.86 \\
\hline & & Net income from the agro-ecosystem & \$/ha & QTL & Economic & Q.S. & 311.15 & 1020.37 & 1585.81 & 1806.04 & 544.01 \\
\hline & & Protein yield from the agro-ecosystem & $\mathrm{kg} / \mathrm{ha}$ & QTL & Ecological & Q.S. & 68.42 & 147.23 & 552 & 373.01 & 318.87 \\
\hline
\end{tabular}

Source: Reference [53]. Legend: QTL = Quantitative; Q.S. = Questionnaire survey.

Table A3. The selected indicators and values to construct single composite indicators for stability.

\begin{tabular}{|c|c|c|c|c|c|c|c|c|c|c|c|}
\hline \multirow{2}{*}{$\begin{array}{l}\text { Sustainability } \\
\text { Category }\end{array}$} & \multirow{2}{*}{$\begin{array}{l}\text { Composite } \\
\text { Indicator }\end{array}$} & \multirow{2}{*}{ Indicators } & \multirow{2}{*}{ Unit } & \multirow{2}{*}{ Data Type } & \multirow{2}{*}{$\begin{array}{l}\text { Sustainability } \\
\text { Pillar }\end{array}$} & \multirow{2}{*}{$\begin{array}{l}\text { Data } \\
\text { Source }\end{array}$} & \multicolumn{5}{|c|}{ Agricultural Systems } \\
\hline & & & & & & & S & SR & $\mathbf{R}$ & I & $\mathrm{T}$ \\
\hline \multirow{15}{*}{ Stability } & \multirow{6}{*}{$\begin{array}{l}\text { Landscape } \\
\text { stability }\end{array}$} & Land exposure to natural events: cyclone & binary yes/no response & QUAL & Ecological & S.D. & 1 & 2 & 2 & 2 & 1 \\
\hline & & Land exposure to natural events: saline water & binary yes/no response & QUAL & Ecological & S.D. & 1 & 1 & 3 & 2 & 3 \\
\hline & & $\begin{array}{l}\text { Land exposure to natural events: drought in the } \\
\text { kharif to rabi season }\end{array}$ & binary yes/no response & QUAL & Ecological & S.D. & 1.5 & 1.5 & 2 & 2 & 3.5 \\
\hline & & Land exposure to natural events: river bank erosion & left & QUAL & Ecological & S.D. & 2 & 2 & 2 & 2 & 1 \\
\hline & & Stability of embankment & binary yes/no response & QUAL & Ecological & F. O. & 1 & 2 & 1 & 2 & 2 \\
\hline & & Withdrawal of upstream water & binary yes/no response & QUAL & Ecological & S.D. & 1 & 1 & 1 & 1 & 2 \\
\hline & \multirow{6}{*}{$\begin{array}{c}\text { Soil } \\
\text { health/stability }\end{array}$} & Organic materials & $\%$ & QTL & Ecological & S.D. & 4 & 4 & 2 & 3 & 2 \\
\hline & & Salinity & $\mathrm{dS} / \mathrm{m}$ & QTL & Ecological & S.D. & 1 & 5 & 6 & 3 & 6 \\
\hline & & Macronutrient: N & $\mathrm{meq} / 100 \mathrm{gm}$ & QTL & Ecological & S.D. & 2 & 2 & 2 & 1 & 2 \\
\hline & & Macronutrient: $\mathrm{P}$ & $\mathrm{meq} / 100 \mathrm{gm}$ & QTL & Ecological & S.D. & 3 & 2 & 3 & 3 & 3 \\
\hline & & Macronutrients: K & $\mathrm{meq} / 100 \mathrm{gm}$ & QTL & Ecological & S.D. & 6 & 4 & 3 & 2 & 4 \\
\hline & & Soil pH & Ratio [no unit] & QTL & Ecological & S.D. & 1 & 3 & 4 & 2 & 4 \\
\hline & \multirow{3}{*}{ Water quality } & $\begin{array}{l}\text { Water salinity in surface water } \\
\text { (quality of surface water for irrigation) }\end{array}$ & $\mathrm{dS} / \mathrm{m}$ & QTL & Ecological & S.D. & 1 & 2 & 2 & 2 & 3 \\
\hline & & $\begin{array}{l}\text { Water salinity in ground water } \\
\text { (quality of ground water for irrigation) }\end{array}$ & $\mathrm{dS} / \mathrm{m}$ & QTL & Ecological & S.D. & 1 & 2 & 2 & 4 & 3 \\
\hline & & $\begin{array}{l}\text { Arsenic concentration } \\
\text { (quality of ground water for irrigation) }\end{array}$ & Ppm & QTL & Ecological & S.D. & 2 & 2 & 2 & 2 & 4 \\
\hline
\end{tabular}

Source: Reference [53]. Legend: QTL = Quantitative; QUAL = Qualitative; S.D. = Secondary data; F.O. = Field observation. 
Table A4. The selected indicators and values to construct single composite indicators for efficiency.

\begin{tabular}{|c|c|c|c|c|c|c|c|c|c|c|c|}
\hline \multirow{2}{*}{$\begin{array}{l}\text { Sustainability } \\
\text { Category }\end{array}$} & \multirow{2}{*}{$\begin{array}{l}\text { Composite } \\
\text { Indicator }\end{array}$} & \multirow{2}{*}{ Indicators } & \multirow{2}{*}{ Unit } & \multirow{2}{*}{ Data Type } & \multirow{2}{*}{$\begin{array}{l}\text { Sustainability } \\
\text { Pillar }\end{array}$} & \multirow{2}{*}{$\begin{array}{l}\text { Data } \\
\text { Source }\end{array}$} & \multicolumn{5}{|c|}{ Agricultural Systems } \\
\hline & & & & & & & $S$ & SR & $\mathbf{R}$ & I & $\mathrm{T}$ \\
\hline \multirow{3}{*}{ Efficiency } & $\begin{array}{l}\text { Monetary } \\
\text { efficiency }\end{array}$ & $\begin{array}{l}\text { Money input and output in the } \\
\text { agro-ecosystem }\end{array}$ & \$ output/ \$ input & QTL & Economic & Q.S. & 1.53 & 2.24 & 2.78 & 6.67 & 2.29 \\
\hline & \multirow{2}{*}{$\begin{array}{l}\text { Energy } \\
\text { efficiency }\end{array}$} & Overall energy efficiency & Ratio of energy output and input & QTL & Ecological & Q.S. & 1.37 & 2.01 & 5.53 & 5.54 & 5.9 \\
\hline & & Non-renewable energy efficiency & Ratio of energy output and input & QTL & Ecological & Q.S. & 0.78 & 0.92 & 2.17 & 2.52 & 2.44 \\
\hline
\end{tabular}

Source: Reference [53]. Legend: QTL = Quantitative; Q.S. = Questionnaire survey.

Table A5. The selected indicators and values to construct single composite indicators for durability.

\begin{tabular}{|c|c|c|c|c|c|c|c|c|c|c|c|}
\hline \multirow{2}{*}{$\begin{array}{l}\text { Sustainability } \\
\text { Category }\end{array}$} & \multirow{2}{*}{$\begin{array}{l}\text { Composite } \\
\text { Indicators }\end{array}$} & \multirow{2}{*}{ Indicators } & \multirow{2}{*}{ Unit } & \multirow{2}{*}{$\begin{array}{l}\text { Data } \\
\text { Type }\end{array}$} & \multirow{2}{*}{$\begin{array}{l}\text { Sustainability } \\
\text { Pillar }\end{array}$} & \multirow{2}{*}{$\begin{array}{l}\text { Data } \\
\text { Source }\end{array}$} & \multicolumn{5}{|c|}{ Agricultural Systems } \\
\hline & & & & & & & $\mathrm{S}$ & SR & $\mathbf{R}$ & I & $\mathbf{T}$ \\
\hline \multirow{10}{*}{ Durability } & \multirow{4}{*}{$\begin{array}{l}\text { Resistance to } \\
\text { pest stress }\end{array}$} & Chemical response to pest stress & binary yes/no response & QUAL & Ecological & Q.S. & 1.78 & 4.17 & 4.24 & 5.45 & 6.54 \\
\hline & & Water availability at transplanting stage of rice & binary yes/no response & QUAL & Ecological & Q.S. & 0.75 & 0.75 & 0.2 & 0.2 & 0.2 \\
\hline & & Water availability at flowering stage of rice & binary yes/no response & QUAL & Ecological & Q.S. & 0.75 & 0.75 & 0.2 & 0.2 & 0.2 \\
\hline & & $\begin{array}{l}\text { Farm management (soil test, pest management, land } \\
\text { management, soil fertility management) }\end{array}$ & binary yes/no response & QUAL & Ecological & Q.S. & 0.67 & 0.83 & 1.69 & 1.36 & 0.0 \\
\hline & \multirow{3}{*}{$\begin{array}{l}\text { Resistance to } \\
\text { economic } \\
\text { stress }\end{array}$} & Good product price & binary yes/no response & QUAL & Economic & Q.S. & 8.44 & 5 & 4.58 & 4.55 & 3.8 \\
\hline & & Availability of seeds & binary yes/no response & QUAL & Ecological & Q.S. & 9.33 & 9.5 & 10 & 10 & 8.85 \\
\hline & & Availability of market (market diversification) & binary yes/no response & QUAL & Social/economic & Q.S. & 10 & 9.17 & 8.47 & 10 & 7.69 \\
\hline & \multirow{3}{*}{$\begin{array}{l}\text { Resistance to } \\
\text { climate change }\end{array}$} & Agricultural training & binary yes/no response & QUAL & Social/ecological & Q.S. & 1.33 & 1.83 & 0.33 & 2.27 & 1.15 \\
\hline & & Climate change awareness & binary yes/no response & QUAL & Social & Q.S. & 1.11 & 0.67 & 0.51 & 1.82 & 0 \\
\hline & & Advice from agricultural extension workers or NGO & binary yes/no response & QUAL & Ecological & Q.S. & 0.66 & 1.17 & 0.51 & 0.45 & 0.38 \\
\hline
\end{tabular}

Source: Reference [53]. Legend: QUAL = Qualitative; Q.S. = Questionnaire survey. 
Table A6. The selected indicators to construct single composite indicators for compatibility.

\begin{tabular}{|c|c|c|c|c|c|c|c|c|c|c|c|}
\hline \multirow{2}{*}{$\begin{array}{l}\text { Sustainability } \\
\text { Category }\end{array}$} & \multirow{2}{*}{$\begin{array}{l}\text { Composite } \\
\text { Indicators }\end{array}$} & \multirow{2}{*}{ Indicators } & \multirow{2}{*}{ Unit } & \multirow{2}{*}{$\begin{array}{l}\text { Data } \\
\text { Type }\end{array}$} & \multirow{2}{*}{$\begin{array}{l}\text { Sustainability } \\
\text { Pillar }\end{array}$} & \multirow{2}{*}{$\begin{array}{c}\text { Data } \\
\text { Source }\end{array}$} & \multicolumn{5}{|c|}{ Agricultural Systems } \\
\hline & & & & & & & $\mathrm{S}$ & SR & $\mathbf{R}$ & I & $\mathrm{T}$ \\
\hline \multirow{5}{*}{ Compatibility } & \multirow{2}{*}{$\begin{array}{l}\text { Human } \\
\text { Compatibility }\end{array}$} & Drinking water quality (protected) & binary yes/no response & QUAL & Ecological & Q.S. & 0 & 8 & 9 & 10 & 9 \\
\hline & & Illness from drinking water & binary yes/no response & QUAL & Ecological & Q.S. & 5 & 10 & 10 & 10 & 10 \\
\hline & \multirow{3}{*}{$\begin{array}{l}\text { Biophysical } \\
\text { Compatibility }\end{array}$} & $\begin{array}{l}\text { Overall biodiversity condition: percentage of } \\
\text { non-crop area }\end{array}$ & $\%$ & QTL & Ecological & Q.S. & 7.54 & 6.48 & 23.01 & 15.73 & 18.68 \\
\hline & & Overall biodiversity condition: crop richness & number of crops & QTL & Ecological & Q.S. & 2 & 6 & 16 & 10 & 17 \\
\hline & & Overall biodiversity condition: crop rotation & number & QTL & Ecological & Q.S. & 2 & 3 & 5 & 4 & 4 \\
\hline
\end{tabular}

Source: Reference [53]. Legend: QTL = Quantitative; QUAL = Qualitative; Q.S. = Questionnaire survey; F.O. = Field observation.

Table A7. The selected indicators and values to construct single composite indicators for equity.

\begin{tabular}{|c|c|c|c|c|c|c|c|c|c|c|c|}
\hline \multirow{2}{*}{$\begin{array}{l}\text { Sustainability } \\
\text { Category }\end{array}$} & \multirow{2}{*}{$\begin{array}{l}\text { Composite } \\
\text { Indicators }\end{array}$} & \multirow{2}{*}{ Indicators } & \multirow{2}{*}{ Unit } & \multirow{2}{*}{$\begin{array}{l}\text { Data } \\
\text { Type }\end{array}$} & \multirow{2}{*}{$\begin{array}{l}\text { Sustainability } \\
\text { Pillar }\end{array}$} & \multirow{2}{*}{$\begin{array}{c}\text { Data } \\
\text { Source }\end{array}$} & \multicolumn{5}{|c|}{ Agricultural Systems } \\
\hline & & & & & & & $\mathrm{s}$ & SR & $\mathbf{R}$ & I & $\mathrm{T}$ \\
\hline \multirow{13}{*}{ Equity } & \multirow{4}{*}{ Education } & Education of farmers & $\%$ & QTL & Social & Q.S. & 8.56 & 9.25 & 4.75 & 10 & 5 \\
\hline & & Education status of farmers' male children & $\%$ & QTL & Social & Q.S. & 10 & 9.49 & 11.2 & 13.1 & 7.45 \\
\hline & & Education status of farmers' female children & $\%$ & QTL & Social & Q.S. & 9.07 & 10.54 & 11.17 & 12.5 & 6.36 \\
\hline & & Access to electronic media & $\%$ & QTL & Social & Q.S. & 7.78 & 9.17 & 9.39 & 10 & 3.08 \\
\hline & \multirow{5}{*}{ Economic } & $\begin{array}{l}\text { Farm profitability (previously it was Income from } \\
\text { agro ecosystem) }\end{array}$ & $\$$ & QTL & Economic & Q.S. & 648.23 & 3340.55 & 1371.32 & 1992.39 & 1025.0 \\
\hline & & Average wage of farm labourer (\$) & $\$ /$ person/day & QTL & Economic & Q.S. & 1.33 & 1.33 & 1.60 & 1.80 & 1.60 \\
\hline & & Livelihood diversity other than agriculture & Count, 0 to 5 & QTL & Economic & Q.S. & 6.22 & 4.33 & 5.93 & 4.55 & 6.92 \\
\hline & & Years of economic hardship & Number of years & QTL & Economic & Q.S. & 0.73 & 0.73 & 0.91 & 0.82 & 0.64 \\
\hline & & $\begin{array}{l}\text { Road network (establishing farm roads and } \\
\text { access roads) }\end{array}$ & Access/not access & QTL & Economic/social & Q.S. & 2 & 3 & 3 & 3 & 1 \\
\hline & \multirow{2}{*}{ Health } & Settings where treatment is taken or public health & $\%$ & QTL & Social & Q.S. & 3.51 & 4.76 & 4.07 & 8.14 & 4.29 \\
\hline & & Sanitation or public health & $\%$ & QTL & Social & Q.S. & 7.69 & 8.73 & 7.59 & 7.41 & 7.08 \\
\hline & \multirow[t]{2}{*}{ Gender } & $\begin{array}{l}\text { Women's involvement in decision making about } \\
\text { agricultural activities }\end{array}$ & $\%$ & QTL & Social & Q.S. & 3 & 4 & 5 & 6.5 & 2.5 \\
\hline & & Gender-based wage differentials & $\$ /$ person/day & QTL & Economic & Q.S. & 0.33 & 0.33 & 0.5 & 0.59 & 0 \\
\hline
\end{tabular}

Source: Reference [53]. Legend: QTL = Quantitative; Q.S. = Questionnaire survey. 
Table A8. The evaluation matrix for agricultural systems for all criteria.

\begin{tabular}{cccccccccccccccc}
\hline A.S. & Pro & LS & SH/S & WQ & ME & EE & RTPS & RTES. & RTCS & HC & BC & Edu & Eco & Hlth & Gen \\
\hline S & 7 & 14 & 15 & 11 & 153 & 7 & 20 & 24 & 22 & 11 & 8 & 20 & 16 & 17 & 16 \\
SR & 16 & 18 & 21 & 18 & 224 & 16 & 26 & 20 & 25 & 22 & 12 & 22 & 22 & 21 & 19 \\
R & 30 & 20 & 21 & 18 & 278 & 30 & 16 & 19 & 10 & 24 & 30 & 20 & 21 & 18 & 26 \\
I & 30 & 21 & 15 & 22 & 667 & 30 & 16 & 20 & 27 & 25 & 21 & 26 & 22 & 25 & 32 \\
T & 14 & 22 & 22 & 29 & 229 & 14 & 14 & 17 & 14 & 24 & 27 & 12 & 15 & 18 & 12 \\
\hline
\end{tabular}

Note: Red numbers indicate the lowest point and green numbers represent the highest point.

\section{References}

1. United Nations (UN). Outcome Document-Open Working Group on Sustainable Development Goals. 2014. Available online: http:/ / sustainabledevelopment.un.org/focussdgs.html (accessed on 5 June 2016).

2. Ness, B.; Urbel-Piirsalu, E.; Anderberg, S.; Olsson, L. Categorising tools for sustainability assessment. Ecol. Econ. 2007, 60, 498-508. [CrossRef]

3. Štreimikienè, D.; Girdzijauskas, S.; Stoškus, L. Sustainability assessment methods and their application to harmonization of policies and sustainability monitoring. Environ. Res. Eng. Manag. 2009, 48, 51-62.

4. Astier, M.; García-Barrios, L.; Galván-Miyoshi, Y.; González-Esquivel, C.E.; Masera, O.R. Assessing the sustainability of small farmer natural resource management systems. A critical analysis of the MESMIS program. Ecol. Soc. 2012, 17, 25. [CrossRef]

5. Bond, A.J.; Morrison-Saunders, A. Sustainability appraisal: Jack of all trades, master of none? Impact Assess. Proj. Apprais. 2009, 27, 321-329. [CrossRef]

6. Gaudreau, K.; Gibson, R.B. Illustrating integrated sustainability and resilience based assessments: A small-scale biodiesel project in Barbados. Impact Assess. Proj. Apprais. 2010, 28, 233-243. [CrossRef]

7. Pretty, J.; Sutherland, W.J.; Ashby, J.; Auburn, J.; Baulcombe, D.; Bell, M.; Bentley, J.; Bickersteth, S.; Brown, K.; Burke, J.; et al. The top 100 questions of importance to the future of global agriculture. Int. J. Agric. Sustain. 2010, 8, 219-236. [CrossRef]

8. Food and Agricultural Organization of United Nations (FAO). Sustainability Assessment of Food and Agriculture Systems (SAFA). 2014. Available online: http:/ /www.fao.org/nr/sustainability/sustainabilityassessments-safa/en (accessed on 10 July 2016).

9. Schader, C.; Grenz, J.; Meier, M.S.; Stolze, M. Scope and precision of sustainability assessment approaches to food systems. Ecol. Soc. 2014, 19, 42. [CrossRef]

10. Häni, F.; Braga, F.; Stämpfli, A.; Keller, T.; Fischer, M.; Porsche, H. RISE, a tool for holistic sustainability assessment at the farm level. Int. Food Agribus. Manag. Rev. 2003, 6, 78-90.

11. Van Cauwenbergh, N.; Biala, K.; Bielders, C.; Brouckaert, V.; Franchois, L.; Cidad, V.G.; Hermy, M.; Mathijs, E.; Muys, B.; Reijnders, J.; et al. SAFE-A hierarchical framework for assessing the sustainability of agricultural systems. Agric. Ecosyst. Environ. 2007, 120, 229-242. [CrossRef]

12. Zahm, F.; Viaux, P.; Vilain, L.; Girardin, P.; Mouchet, C. Assessing farm sustainability with the IDEA method-from the concept of agriculture sustainability to case studies on farms. Sustain. Dev. 2008, 16, 271-281. [CrossRef]

13. Meul, M.; Van Passel, S.; Nevens, F.; Dessein, J.; Rogge, E.; Mulier, A.; Van Hauwermeiren, A. MOTIFS: A monitoring tool for integrated farm sustainability. Agron. Sustain. Dev. 2008, 28, 321-332. [CrossRef]

14. Van Ittersum, M.K.; Ewert, F.; Heckelei, T.; Wery, J.; Olsson, J.A.; Andersen, E.; Bezlepkina, I.; Brouwer, F.; Donatelli, M.; Flichman, G.; et al. Integrated assessment of agricultural systems-A component-based framework for the European Union (SEAMLESS). Agric. Syst. 2008, 96, 150-165. [CrossRef]

15. Dantsis, T.; Douma, C.; Giourga, C.; Loumou, A.; Polychronaki, E.A. A methodological approach to assess and compare the sustainability level of agricultural plant production systems. Ecol. Indic. 2010, 10, 256-263. [CrossRef]

16. Talukder, B.; Saifuzzaman, M. Sustainability of agricultural systems in the coastal zone of Bangladesh. Renew. Agric. Food Syst. 2016, 31, 148-165. [CrossRef]

17. Triantaphyllou, E. Multi-Criteria Decision Making Method: A Comparative Study; Kluwer Academic Publishers: Dordrecht, The Netherlands, 2000. 
18. Belton, S.; Stewart, T.S. Multiple Criteria Decision Analysis: An Integrated Approach; Kluwer Academic Publishers: Hingham, MA, USA, 2002.

19. Figueira, J.; Salvatore, G.; Matthias, E. Multiple Criteria Decision Analysis: State of the Art Surveys; Springer Science + Business Media, Inc.: New York, NY, USA, 2005; ISBN 0-387-23081-5.

20. North, D.W. A Tutorial Introduction to Decision Theory. IEEE Trans. Syst. Sci. Cybern. 1968, 4, 200-210. [CrossRef]

21. Alencar, L.H.; Almeida, A.T.D. A model for selecting project team members using multicriteria group decision making. Pesqui. Oper. 2010, 30, 221-236. [CrossRef]

22. Jeon, C.M.; Amekudzi, A.A.; Guensler, R.L. Evaluating Plan Alternatives for Transportation System Sustainability: Atlanta Metropolitan Region. Int. J. Sustain. Transp. 2010, 4, 227-247. [CrossRef]

23. Köksalan, M.M.; Wallenius, J.; Zionts, S. Multiple Criteria Decision Making: From Early History to the 21st Century; World Scientific: Singapore, 2011.

24. Dodgson, J.S.; Spackman, M.; Pearman, A.; Phillips, L.D. Multi-Criteria Analysis: A Manual; Department for Communities and Local Government: London, UK, 2009. Available online: http:/ / eprints.lse.ac.uk/12761/ 1/Multi-criteria_Analysis.pdf (accessed on 15 October 2017).

25. Zietsman, J.; Rilett, L.R.; Kim, S.J. Transportation corridor decision-making with multi-attribute utility theory. Int. J. Manag. Decis. Mak. 2006, 7, 254-266. [CrossRef]

26. Wang, J.J.; Jing, Y.Y.; Zhang, C.F.; Zhao, J.H. Review on multi-criteria decision analysis aid in sustainable energy decision-making. Renew. Sustain. Energy Rev. 2009, 13, 2263-2278. [CrossRef]

27. EAF Planning and Implementation Tools (EAF). Multi-Criteria Decision Analysis (MCDA) Also Known as Multi-Objective Decision Analysis (MODA); EAF Tool Fact Sheets; EAF Net Team: Rome, Italy, 2011. Available online: http:/ / www.fao.org/fishery / eaf-net/eaftool/eaf_tool_31/en (accessed on 17 January 2018).

28. Herath, G.; Prato, T. Role of multi-criteria decision making in natural resource management. In Using Multi-Criteria Decision Analysis in Natural Resource Management; Herath, G., Prato, T., Eds.; Ashgate: Farnham, UK, 2006.

29. Tsoutsos, T.; Drandaki, M.; Frantzeskaki, N.; Iosifidis, E.; Kiosses, I. Sustainable energy planning by using multi-criteria analysis application in the island of Crete. Energy Policy 2009, 37, 1587-1600. [CrossRef]

30. Psomas, A.; Vryzidis, I.; Spyridakos, A.; Mimikou, M. MCDA approach for agricultural water management in the context of water-energy-land-food nexus. Oper. Res. 2018, 1-35. [CrossRef]

31. Saaty, T.L. Decision Making for Leaders: The Analytic Hierarchy Process for Decisions in A Complex World; RWS Publications: Pittsburgh, PA, USA, 1990.

32. Saaty, T.L. Theory and Applications of the Analytic Network Process: Decision Making with Benefits, Opportunities, Costs, and Risks; RWS Publications: Pittsburgh, PA, USA, 2005.

33. Keeney, R.L.; Raiffa, H. Decisions with Multiple Objectives: Preferences and Value Trade-Offs; Cambridge University Press: Cambridge, UK, 1993.

34. Greco, S.; Figueira, J.; Ehrgott, M. Multiple Criteria Decision Analysis; Springer: New York, NY, USA, 2016.

35. Roy, B. The outranking approach and the foundations of ELECTRE methods. In Readings in Multiple Criteria Decision Aid; Springer: Berlin/Heidelberg, Gremany, 1990; pp. 155-183.

36. Mareschal, B.; Brans, J.P.; Vincke, P. PROMETHEE: A New Family of Outranking Methods in Multicriteria Analysis (No. 2013/9305); ULB-Universite Libre de Bruxelles: Bruxelles, Belgium, 1984.

37. Martel, J.M.; Matarazzo, B. Other outranking approaches. In Multiple Criteria Decision Analysis: State of the Art Surveys; Springer: New York, NY, USA, 2005; pp. 197-259.

38. Opricovic, S.; Tzeng, G.H. Compromise solution by MCDM methods: A comparative analysis of VIKOR and TOPSIS. Eur. J. Oper. Res. 2004, 156, 445-455. [CrossRef]

39. Cinelli, M.; Coles, S.R.; Kirwan, K. Analysis of the potentials of multi criteria decision analysis methods to conduct sustainability assessment. Ecol. Indic. 2014, 46, 138-148. [CrossRef]

40. Devuyst, D. Linking impacts assessment and sustainable development at the local level: The introduction of sustainable assessment systems. Sustain. Dev. 2000, 8, 67-78. [CrossRef]

41. Gibson, R.B.; Hassan, S.; Holt, S.; Tansy, J.; Whitelaw, G. Sustainability Assessment: Criteria and Process; Earthscan Publications: London, UK, 2005.

42. Behzadian, M.; Kazemzadeh, R.B.; Albadvi, A.; Aghdasi, M. PROMETHEE: A comprehensive literature review on methodologies and applications. Eur. J. Oper. Res. 2010, 200, 198-215. [CrossRef] 
43. Sadok, W.; Angevin, F.; Bergez, J.E.; Bockstaller, C.; Colomb, B.; Guichard, L.; Reau, R.; Dore, T. Ex ante assessment of the sustainability of alternative cropping systems: Implications for using multi-criteria decision-aid methods. A review. Agron. Sustain. Dev. 2008, 28, 163-174. [CrossRef]

44. Batstone, C.J.; Baines, J.M.; Goodwin, E.; Morgan, B.; Canard, T. Methods for Developing Sustainability Indictor Systems for Freshwater and Estuarine Receiving Bodies of Urban Storm Water. Prepared for NIWA. Cawthron Report No. 1874. 2010, p. 55. Available online: https:/ /www.niwa.co.nz/sites/niwa.co.nz/files/ upsw3.pdf (accessed on 10 August 2016).

45. Linkov, I.; Moberg, E. Multi-Criteria Decision Analysis: Environmental Applications and Case Studies; CRC Press: Boca Raton, FL, USA, 2011.

46. Wood, M.D.; Bostrom, A.; Bridges, T.; Linkov, I. Cognitive mapping tools: Review and risk management needs. Risk Anal. 2012, 32, 1333-1348. [CrossRef] [PubMed]

47. Loken, E. Use of multicriteria decision analysis methods for energy planning problems. Renew. Sustain. Energy Rev. 2007, 11, 1584-1595. [CrossRef]

48. Talukder, B.; Blay-Palmer, A.; Hipel, K.W.; vanLoon, G.W. Elimination Method of Multi-Criteria Decision Analysis (MCDA): A Simple Methodological Approach for Assessing Agricultural Sustainability. Sustainability 2017, 9, 287. [CrossRef]

49. Talukder, B.; Hipel, K.W.; vanLoon, G.W. Using multi-criteria decision analysis for assessing sustainability of agricultural systems. Sustain. Dev. 2018, 1-19. [CrossRef]

50. De Luca, A.I.; Iofrida, N.; Falcone, G.; Stillitano, T.; Gulisano, G. Olive growing scenarios of soil management: Integrating environmental, economic and social indicators from a life-cycle perspective. Acta Hortic. 2018, 1199, 209-214. [CrossRef]

51. De Luca, A.I.; Falcone, G.; Stillitano, T.; Iofrida, N.; Strano, A.; Gulisano, G. Evaluation of sustainable innovations in olive growing systems: A Life Cycle Sustainability Assessment case study in southern Italy. J. Clean. Prod. 2018, 171, 1187-1202. [CrossRef]

52. De Luca, A.I.; Iofrida, N.; Leskinen, P.; Stillitano, T.; Falcone, G.; Strano, A.; Gulisano, G. Life cycle tools combined with multi-criteria and participatory methods for agricultural sustainability: Insights from a systematic and critical review. Sci. Total Environ. 2017, 595, 352-370. [CrossRef] [PubMed]

53. Falcone, G.; De Luca, A.I.; Stillitano, T.; Strano, A.; Romeo, G.; Gulisano, G. Assessment of environmental and economic impacts of vine-growing combining life cycle assessment, life cycle costing and multicriterial analysis. Sustainability 2016, 8, 793. [CrossRef]

54. Antunes, P.; Santos, R.; Videira, N.; Colaço, F. Approaches to Integration in Sustainability Assessment of Technologies. In Guidelines for the Application of MCA-Tools for the Sustainability Assessment of Technologies in Participatory Contexts and Weighing Factors for Environmental, Economic, and Social Indicators; Report Prepared within the EC 7th Framework Project; 2012. Available online: http://www.prosuite.org/c/document_ library /get_file?uuid=c378cd69-f785-40f2-b23e-ae676b939212\&groupId=12772 (accessed on 12 May 2017).

55. Cavallaro, F. Assessment and Simulation Tools for Sustainable Energy Systems: Theory and Applications; Springer Science \& Business Media: Berlin/Heidelberg, Germany, 2013; Volume 129.

56. PROMETHEE 1.4 Manual. 2013. Available online: http://www.promethee-gaia.net/visual-promethee.html (accessed on 10 June 2016).

57. Brans, J.P.; Mareschal, B. PROMETHEE methods. In Multi Criteria Decision Analysis: State of the Art Surveys; Greco, S., Ehrgott, M., Figueira, J., Eds.; Springer: New York, NY, USA, 2005.

58. Nasiri, H.; Alavipanah, S.K.; Matinfar, H.R.; Azizi, A.; Hamzeh, M. Implementation of agricultural ecological capability model using integrated approach of PROMETHEE II and fuzzy-AHP in GIS environment (Case Study: Marvdasht county). J. Environ. Stud. 2012, 38, 28-30.

59. Macharis, C.; Springael, J.; De Brucker, K.; Verbeke, A. PROMETHEE and AHP: The design of operational synergies in multicriteria analysis. Strengthening PROMETHEE with ideas of AHP. Eur. J. Oper. Res. 2004, 153, 307-317. [CrossRef]

60. Geldermann, J.; Rentz, O. Integrated technique assessment with imprecise information as a support for the identification of best available techniques (BAT). OR-Spektrum 2001, 23, 137-157. [CrossRef]

61. Brinkhoff, P. Multi-Criteria Analysis for Assessing Sustainability of Remedial Actions Applications in Contaminated Land Development; A Literature Review; Chalmers University of Technology: Göteborg, Sweden, 2011. Available online: http:/ / publications.lib.chalmers.se/records/fulltext/150656.pdf (accessed on 10 September 2017). 
62. Lerche, N.; Schmehl, M.; Geldermann, J. Sustainability Assessment of Concepts for Energetic Use of Biomass: A Multi-Criteria Decision Support Approach. In Operations Research Proceedings; Springer: Cham, Switzerland, 2014; pp. 77-82.

63. Food and Agricultural Organization of United Nations (FAO). Sustainability Path Way. 2013. Available online: http:/ / www.fao.org/nr/sustainability/en/ (accessed on 12 July 2016).

64. Jackson-Smith, D. Toward Sustainable Agricultural Systems in the 21st Century; National Academies Press: Washington, DC, USA, 2010.

65. Van Loon, G.W.; Patil, S.G.; Hugar, L.B. Agricultural Sustainability: Strategies for Assessment; Sage: New Delhi, India, 2005.

66. Bangladesh Bureau of Statistics (BBS). Ministry of Planning; Bangladesh Bureau of Statistics (BBS): Dhaka, Bangladesh, 2010.

67. Talukder, B. Sustainability of Changing Agricultural Systems in the Coastal Zone of Bangladesh. Master's Thesis, Environmental Studies, Queen's University, Kingston, ON, Canada, 2012.

68. Bangladesh Bureau of Statistics (BBS). Ministry of Planning; Bangladesh Bureau of Statistics (BBS): Dhaka, Bangladesh, 2008.

69. Talukder, B.; Hipel, K.W.; vanLoon, G.W. Developing Composite Indicators for Agricultural Sustainability Assessment: Effect of Normalization and Aggregation Techniques. Resources 2017, 6, 66. [CrossRef]

70. Rahman, S.; Barmon, B.K. Energy productivity and efficiency of the 'gher' (prawn-fish-rice) farming system in Bangladesh. Energy 2012, 43, 293-300. [CrossRef]

71. Schmidtmann, B.; Uskova, G.; Uhlemair, H.; Geldermann, J. A Comparison of Two Visualisation Methods for Decision Support in MCDM Problems. In Operations Research Proceedings; Springer International Publishing: Cham, The Netherlands, 2014; pp. 83-89.

72. Hyde, K.; Maier, H.R.; Colby, C. Incorporating uncertainty in the PROMETHEE MCDA method. J. Multi-Criteria Decis. Anal. 2003, 12, 245-259. [CrossRef]

73. Bossel, H. Assessing viability and sustainability: A systems-based approach for deriving comprehensive indicator sets. In Integrated Natural Resource Management: Linking Productivity, the Environment and Development; CABI Publishing: New York, NY, USA, 2003; pp. 247-266.

74. Gavade, R.K. Multi-Criteria Decision Making: An overview of different selection problems and methods. Int. J. Comput. Sci. Inf. Technol. 2014, 5, 5643-5646.

75. Organisation for Economic Co-Operation and Development (OECD). Handbook on Constructing Composite Indicators: Methodology and User Guide; Joint Research Centre-European Commission: Paris, France, 2008.

76. Morais, D.C.; de Almeida, A.T.; Alencar, L.H.; Clemente, T.R.N.; Cavalcanti, C.Z.B. PROMETHEE-ROC Model for Assessing the Readiness of Technology for Generating Energy. Math. Probl. Eng. 2015, 2015, 530615. [CrossRef]

77. United Nations-Sustainable Development Goal (UN-SDG). Sustainable Development Goal Indicators. 2015. Available online: http:/ / unstats.un.org/sdgs / (accessed on 3 May 2016).

78. David, G.; Stafford-Smith, M.; Gaffney, O.; Rockström, J.; Öhman, M.C.; Shyamsundar, P.; Steffen, W.; Glaser, G.; Kanie, N.; Noble, I. Sustainable development goals for people and planet. Nat. Int. Wkly. J. Sci. 2013, 495, 305-307.

(C) 2018 by the authors. Licensee MDPI, Basel, Switzerland. This article is an open access article distributed under the terms and conditions of the Creative Commons Attribution (CC BY) license (http://creativecommons.org/licenses/by/4.0/). 